\title{
Principles of surgical management of adult cavus foot
}

\author{
Hossam Kandil MD \\ Department of Peadiatric Orthopedic Surgery. \\ National Institute Neuromotor System and Rehabilitation
}

\begin{abstract}
Back ground: Cavusfoot is a complex deformity with an abnormally high arch. It is the result of the problem, and is itself the problem. It needs complete evaluation, classification, and management. The aim of this study to evaluate the new advances in the surgical treatment of adult idiopathic cavus foot.

Material and Method: Twenty nine patients with thirty eight idiopathic cavus feet were assessed and evaluated clinically and radiologically They were subdivided into 2 groups:- group A received surgical management including soft tissue release and anterior tarsal wedge osteotomy, group B received surgical management including soft tissue release and triple arthrodesis.
\end{abstract}

Results: The assessment of the results showed that there were significant improvement in all parameters in both groups and satisfactory results were considered obtained in twenty nine feet $76.31 \%$

Conclusion: Cavus foot is not alike. Surgical management must be individualized based on the age of patient, flexibility or rigidity of the deformity. I believe that correction of the deformities begins with soft tissue release. The anterior tarsal osteotomy is the best choice for cavus foot with correctable heel in young adult, and triple arthrodesis should be reserved as a salvage procedure for severe, rigid, combined deformity in older patients.

\section{Introduction}

Cavus foot is a foot with an abnormally high arch. While it is difficult to ascribe a particular threshold of arching beyond which treatment is necessary, most deform -ities are dramatic enough to make diagnosis straight forward. While it is not rare, the incidence is not well established. The etiology of idiopathic cavus foot is yet unknown, and no definite cause is discovered. However, it is caused by a neurologic disorder in which the only symptom is the cavus foot $(6,9)$.

Morphologically ICF is a complex deformity, can be defined as a plantar flexed forefoot, a dorsiflexed and varus hind foot, and subsequent elevation of plantar arch frequently associated with claw deformity of the toes. During gait, the complex deformity produce freq uent ankle sprain, soft tissue overlo ading and stretching, adaptive second ary bones and joints changes, and foot wear problem Fig $(1)(7,10)$. 


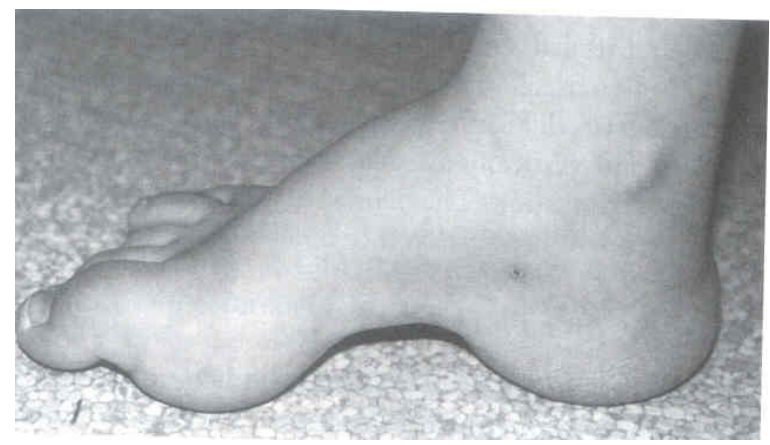

Fig (1) The typical morphologic appearance of a cavus foot

The exact pathogenesis of ICF is not clear. It is due to an imbalance of extrinsic - intrinsic muscles of the foot, soft tissue fibrosis, capsule contractures, and bony abnormality. The most widely recent theory maintains that first metatarsal bone is plantar flexed because of an imbalance between a strong peroneus longus muscle and a week tibialis anterior muscle and denervation and weakness of intrinsic muscles of the foot. $(11,13)$.

The diagnosis of ICF must be one of exclusion after through diagnostic efforts, including complete neuromuscular assessment, E.M.G., and nerve conduction studies, and possibly a muscle biopsy. Roentgenographic finding may be helpful in establishing a diagnosis and determining appropriate surgical treatment. Fig $2(1,2)$

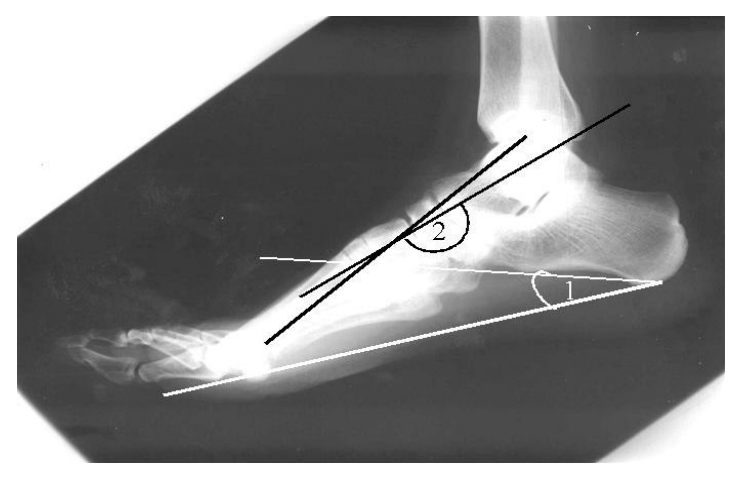

Fig (2) Radiograph illustrating (Normal foot).

1. The calcaneal pitch measurement $\leq 30$

2. The arch angel measurement (Talo 1 st metatarsal )160 - 170 . 
The aim of treatment of ICF is to correct the deformity, rebalance the foot, and provide a plantigrade foot. The treatment depends on the precise etiology of the problem, and extent of the deformities and bony abnormality present. Their are many surgical techniques have been described, including soft tissue, bony, articular, and combined procedures. It begins with soft tissue release, and osteotomies are used to correct secondary bone deformities that can be identified after soft tissue release. They include osteotomy of first metatarsal, wedge osteotomy of the medial cuneiform., mid foot osteotomy, and a posterior calcaneus osteotomy. Triple arthrodesis should not be used as primary reconstructive technique in young adolescent.

The purpose of the present study was to review the results of combined procedures in adult idiopathic cavus foot, with the different, complex deformities. $(4,5,14,15)$

\section{Material and Method}

A prospective study was carried on 29 patients with 38 idiopathic cavus feet. They were collected from orthop eadic department of National Institute of Neuro-motor system and Rehabilitation. The mean age at presentation was 15.6 years (11.522.3 years) and bilateral affected at 9 patients $31 \%$.

In this study, all patient had received a complete clinical, radiolo gical, and gait analysis, and the patients who had neurologic disorders was excluded. Complete clinical examin ation and analysis of foot deformity were performed, including; ankle movement (dorsiflexion - plantar flexion), hind foot deformity (varus heel), forefoot deformity (equinus forefoot), and complex deformities (supination foot).

Standing lateral and anteroposterior radiographs were performed, and the arch angle, calcaneal pitch, were measured. $(8,12)$

\section{Surgical management:-}

The patients were divided into two groups according the flexibility of hind foot with manual testing, and lateral block test (3): patient stand on a block of wood about 1 inches higher. Planterflexed first metatarsal is allowed to hang free from block, this eliminates the effect of fixed forefoot pronation on the hind foot. If the heel goes into valgus position, the hind foot is supple, if the heel remains in varus, the hindfoot is considered rigid .

Group(A) 14 patients with 16 feet in which the cavus deformity occurs at mid tarsal Joints and the hind foot component was flexible with manual testing and lateral block test. The surgical operation was consisted of an open plantar fasciotomy through a $2-\mathrm{cm}$ medial approach and combined anterior tarsal wedge osteotomy naviculocuneiform arthrodesis, and cuboid osteotomy-through two incisions medial and lateral of the dorsum of foot. Group(B) 15 patients with 22 feet in which combined cavus deformity occurs (calcanco varus defomity), in which fore foot is in adduction and equinus deformity and hind foot is in varus deformity. There was rigidity of all deformities that associted with disability of the ankle Joint. The surgical operation consisted of an open plantar fasciotomy through a 2-cm medial approach and triple arthrodesis through dorso-lateral approach from the lateral aspect of head of the talus inferiorly and posteriorly to a point below the end of the fibula. The wedge of bone must be 


\section{Hossam Kandil MD}

carefully planned to correct the multiplane deformity. Below knee cast immobilization was needed for 12 weeks, then weight bearing was allowed.

\section{Additional procedures:-}

- Group A- Posterior calcaneal osteotomy was performed in 2 feet in persisting varus deformity.

- Group B- Modified Jones procedures was performed in 9 feet in claw toe deformity of the great toe.

\section{Results}

Clinical evaluation was perfor med as regard pain, activity of daily living, range of ankle motion, deformity of hindfoot, and deformity of forefoot, using a Modified Maryland Foot Score table (1). Each item is given a certain score, and cases with 90 to 100 points are considered as excellent, 75 to 89 points as good, 50 to 75 points as fair, and 50 or less as poor. Radiological evaluation was made from standing lateral and anteroposterior views of the affected foot.

Table (1) : A Modified Maryland Foot Score.

\begin{tabular}{|l|c|}
\hline 1-Pain (20 point) & \\
-No pain & 20 \\
-Occasional pain & 15 \\
-Moderate pain with use of medication & 10 \\
-Sever pain with use of medication & 5 \\
\hline 2-Activity of daily living (20 point) & \\
-No change & 20 \\
-Modified without difficult & 15 \\
-Modified with difficult & 10 \\
-Disability & 5 \\
& \\
\hline 3-Ankle range of motion (20 point) & 20 \\
-5-0-75degree & 10 \\
-25-50 degree & 5 \\
-Less than 25 degree & \\
\hline 4-Hind foot deformity (20 point) & 5 \\
-Varus $>5$ degree & 10 \\
-Varus 0-5 degree & 15 \\
-Neutral 0 & 20 \\
-Valgus $<5$ degree & \\
\hline 5-Fore foot deformity (20 point) & 5 \\
-Sever cavus & 10 \\
-Moderate cavus & 20 \\
-Mild cavus & \\
-Plantegrade & \\
& \\
\hline
\end{tabular}


Clinical results showed that the improvements in all parameters in both groups and Satisfactory results were considered obtained in 29 feet $76.31 \%$. table (2)
Persistance of pain, and changes of activity of daily living were the main reason of decreasing the score in the unsatisfactory cases.

Table (2) clinical results.

\begin{tabular}{|l|lc|lc|lc|}
\hline & \multicolumn{2}{|l|}{$\begin{array}{l}\text { gral patients (A) } \\
\text { No. }\end{array}$} & $\%$ & $\begin{array}{l}\text { group (B) } \\
\text { No. }\end{array}$ & $\%$ & \multicolumn{2}{l|}{ No. } & $\%$ \\
\hline Satisfactory: & & & & & & \\
Excellent & 14 & 36.84 & 8 & 50 & 6 & 27.27 \\
Good & 15 & 39.47 & 5 & 31.25 & 10 & 45.45 \\
\hline Unsatisfactory: & 5 & & & & & \\
Fair & 4 & 13.15 & 2 & 12.5 & 3 & 13.63 \\
Poor & 10.22 & 1 & 6.25 & 3 & 13.63 \\
\hline
\end{tabular}

In group(A) the mean ankle dorsiflexion was $6^{\circ}$ preoperatively, and $10^{\circ}$ post operatively $\mathrm{p}<0.05$, and mean ankle plantarflexion was $28^{\circ}$ preoperatively, and $35^{\circ}$ postoperatively $\mathrm{p}<0.05$. The mean heel alignment was $4^{\circ}$ varus, and $2^{\circ}$ of valgus postoperatively $\mathrm{p}<0.001$.

In group(B) the mean ankle dorsiflexion was $3^{\circ}$ preoperatively, and $13^{\circ}$ postoperatively $\mathrm{p}<0.005$, mean ankle plantarflexion was $15^{\circ}$ preoperatively, and $35^{\circ}$ postoperatively $\mathrm{p}<0.001$. The mean heel alignment was $11^{\circ}$ of varus preoperatively and $5^{\circ}$ of valgus postoperatively $\mathrm{p}<0.001$.

The calcaneal pitch and arch angle were recorded and compared with normal range. table (3)

\section{Table (3) radiological results.}

\begin{tabular}{|l|l|lc|lc|}
\hline & Normal & Group(A) & & Group(B) \\
Pre. & Post. & Pre. & Post. \\
\hline Calcancal pitch & $30-^{+}$ & 41 & 32 & 64 & 32 \\
\hline Arch angle & $160-170$ & 126 & 158 & 114 & 165 \\
\hline
\end{tabular}

\section{Case Reports}

\section{Case (1)}

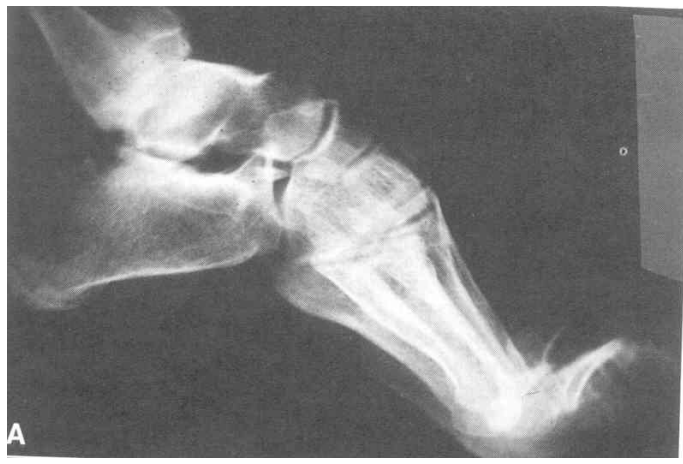

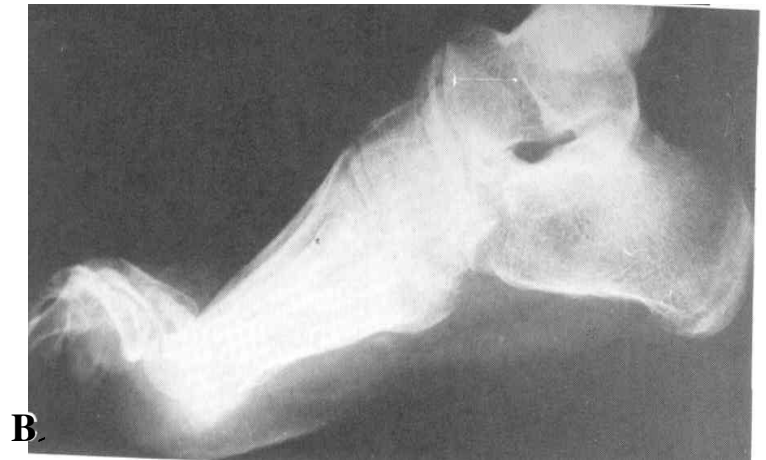

Fig (3) :- A 14 years old man with ICF was manged with plantar fasciotomy anterior Tarsal arthrodesis and cvboid osteatomy Radiographs made before surgery (A), and 3 years after surgery (B). 
A.

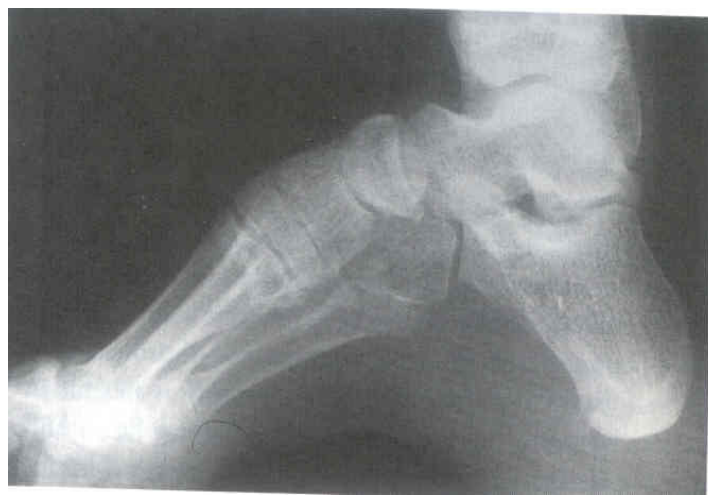

B.

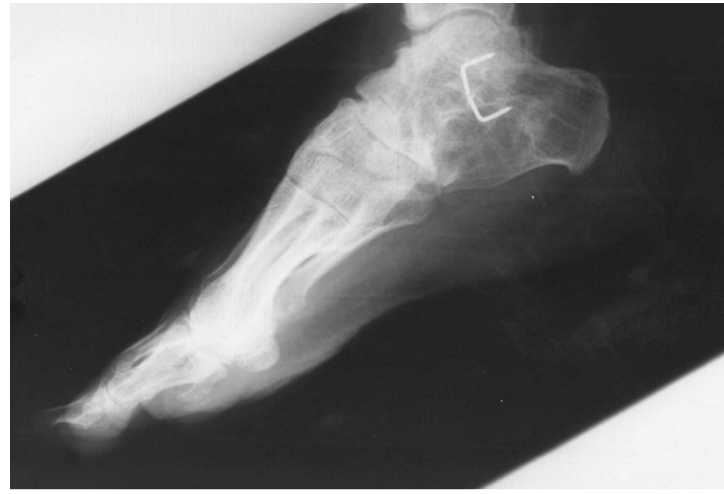

Fig (4) :- 19 years old patient with ICF was managed with with plantar fasciotomy and triple arthrodesis. Radiographs made before surgery (A), and 4 years after surgery ( B).

\section{Discussion}

Cavus is much more complex and difficult to mange foot deformity than well known and frequently foot deformities. However, they share a fixed equinus deformity of the forefoot in relation to the hind foot that results are an abnormally high arch. In addition, there are two major rotational deformities in opposite direction for each other pronation of forefoot, and supination - varus of hind foot.

The evaluation, classification, and management of cavus foot deformities are not standardized. The underlying neuromuscular abnormality is known at time of presentation in some patients and not in other. Some are treatable, many are not. Some cases are static and some are progressive. So it is important to establish the etiology of the cavus foot before treating the deformity and consultation by a peadiatric neurologist is appropriate.

There is a long list of surgical procedures that can be used to correct the individual deformities. They can subdivided into soft tissue, bony, articular, and combined procedures, but no one procedure can accomplish the goal of treatment.

In this study, Instead of no classification system to help one choose the procedures that will best address the unique pathology in any particular patient, the correction requires two closely staged surgical procedures. ie soft tissue release, and corrective osteotomy. Selection of surgical treatment depends on flexibility of the deformity, the age of patient, and the underlying severity of the deformity.

For all patients the correction begins with soft tissue procedures ie open medial plantar release - abductor hallucis, short toe flexors, and plantar fascia. In anterior cavus deformity ie plantar flexion of forefoot and flexible varus heal the anterior tarsal wedge osteotomy procedure provides good correction of deformity, permits the correction of secondary varus deformity of hind foot, and preserves motion in subtalar joint. The best results were obtained when the operation was performed in patient before secondary skeletal deformities occur. On the other hand, in severe, combined cavus deformity ie adduction and pronation of forefoot and rigid varus and supination of hind foot. The triple arthrodesis was indicated. It acts as a salvage procedure for existing severe bony deformity and ostearthritis changes in older patients 
that not amenable to procedures that will retain joint motion.

\section{Conclusion}

A long list of surgical procedures that can be used to correct the cavus foot. Surgical management must be individualized based on the age of patient ,flexibility and severity of the deformity.

\section{Referances}

1. Alexander I, Johnson $\mathbf{K}$ : Assessment and mangement of pes cavus in Charcot - Marie - tooth disease. Clin Orth. $246: 273,1989$.

2. Cole. W: The treatment of claw foot. Clin Orth 181, 1983.

3. Coleman. S, and Chesnut W.:Asimple test for hind foot flexibility in cavovarus foot Clin Orth 123 : 60, 1977.

4. Dekel S, and Weissman S.:Osteotomy of the calcaneus and concomitant plantar stripping in children with T.E.V.: J. Bone Joint Surg. B. 55: 802, 1973.

5. Evans D.:- Relapsed clubfoot. J Bone Joint Surg B. 43: 722, 1961.

6. Jahss MH.:- Evaluation of cavus foot for orthopeadic treatment, Clin Orth $181: 52.1983$.
7. Mann RA., and Missirian J:Pathophysiology of Charcot-Marietooth disease, Clin Orth 232, 1988.

8. Paulos L, Colemann SS, and Samuelson K.M.:- review of surgical approach using selective soft tisue procedures J. Bone Joint Surg 62 A, 1980.

9. Roger AM.:- Adult ankle and foot, Turek's Orthopaedic: Principles and their Application $5^{\text {th }}$ ed, lippincott com. Philadelphia, 1994.

10.Sabir M. and Lyttle D:Pathogenesis of pescavus in charcot - Marie - tooth disease, Clin Orth $175: 173,1983$.

11. Samilson RL and Dillin W:Cavus, Cavovarus, and Calcaneocavus: an update. Clin Orth. $177:$ 125, 1983.

12. Simons. G.W.:- Complete subtalar release in clubfoot $\mathrm{J}$ Bone and Joint Surg 67 (A) : 1044, 1985.

13. Swanson A.B, etal:- The cavus foot, concepts of production and treatment by metatarsal osteotomy. $\mathrm{J}$ Bone Joint Surg 48 A: 1019, 1966.

14. Vincent. SL:- The cavus foot. Pediatric Orth 21. 423, 2001.

15. Wetmore R.S. and Drennan J.A.:Long tearm results of triple arthrodesis in charcot - Marie tooth disease, J Bone Joint Surg: A 71: 418, 1989. 


\section{العلاج الجر احي للتشوه القدم المخلبية للكبار \\ د/ حسام محمد قنديل}

$$
\text { زميل جراحة العظام والكسور ( قسم جراحة عظام الأطفال ) }
$$

يعتبر القدم المخلبية من تشوهات القدم المعقدة التي تؤدي إلي ارتفاع قوس القـــدم إلي أعلــي

و هي تحتاج إلي تقييم كامل للقدم مع تحديد درجة التشوه وتيبس مفاصل القدم المصاحب له.

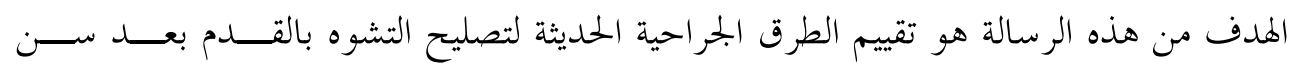

$$
\text { البلوغ. }
$$

تم عمل البحث علي 29 مريض مع 38 قدم مخلبية التشوه، وتم التقييم الإكلينيكي مع الأشعة التشخيصية،

$$
\text { وتم عمل عمليات جراحية لتصليح التشوه علي بحموعتين: }
$$

وتشمل عملية شق عظمي لتصليح التشوه بالبحموعة الأولي وعملية سمكرة قدم بالبمموعة الثانية. نستخلص من هذه الرسالة بعد التقييم الكامل للنتائج العمليات الجراحية:

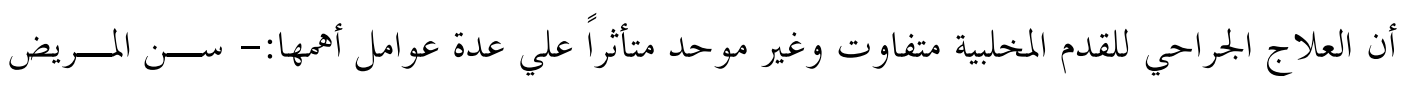
وقت التشخيص، ونوع التشوه بالقدم، و تأثره علي المريض، و التغيرات الباثولوجية لعظام ومفاصل القدم

ومدى حر كة مفاصل القدم مع التشوه هـا.

أن عمليات تسليك القدم مع الشق العظيمي تستخدم لعلاج تشوه القدم ذات مدي حر كة بالمفاصـل للسن الصغير، وعمليات سمكرة القدم تستخدم لعلاج القدم ذات التشوه الشديد المتيبس للسن الكبير. 